\title{
MODEL BERBASIS SIR \\ DALAM PREDIKSI AWAL PENYEBARAN COVID-19 DI DAERAH ISTIMEWA YOGYAKARTA (DIY)
}

\author{
(SIR-BASED MODEL \\ IN PREDICTING THE EARLY OUTBREAK OF COVID-19 \\ IN THE SPECIAL REGION OF YOGYAKARTA (DIY))
}

\author{
FAJAR ADI-KUSUMO, NANANG SUSYANTO*, \\ IRWAN ENDRAYANTO, ANDREASTA MELIALA
}

\begin{abstract}
Abstrak. Pandemi COVID-19 yang muncul pertama kali pada akhir tahun 2019 saat ini telah menyebar ke seluruh dunia dan mempengaruhi segala sendi kehidupan manusia. Di Indonesia, kasus ini mulai berkembang sejak akhir bulan Februari 2020 dan hingga saat ini masih terus terjadi peningkatan infeksi baru. Beberapa model dan prediksi kasus COVID-19 di Indonesia telah dilakukan oleh para peneliti, namun hasilnya belum sepenuhnya akurat. Hal ini kemungkinan disebabkan adanya pola yang berbeda-beda di setiap daerah, sehingga prediksi yang dilakukan di tingkat nasional perlu mengakomodir perbedaan pola tersebut. Pada artikel ini, akan diperkenalkan model matematika untuk melakukan prediksi awal kasus COVID-19 di wilayah Daerah Istimewa Yogyakarta. Pemodelan dilakukan berbasis model SIR yang parameter-parameternya diestimasi berdasarkan data. Dengan menggunakan model tersebut, akan dikaji dua skenario yang bersifat optimistik dan pesimistik.
\end{abstract}

Kata-kata kunci: COVID-19, SIR, coronavirus, prediksi.

\begin{abstract}
The COVID-19 pandemic, which first appeared at the end of 2019, has now spread throughout the world and affected all aspects of human life. In Indonesia, this case began to develop since the end of February 2020 and until now there is still an increase in new infections. Several models and predictions of COVID-19 cases in Indonesia have been carried out by researchers, but the results are not yet fully accurate. This is likely due to the different patterns in each region, so the predictions made at the national level need to accommodate these different patterns. In this article, a mathematical model will be introduced to make initial predictions of the COVID-19 case in the Yogyakarta Special Region. Modeling is carried out based on the SIR model whose parameters are estimated based on data. We consider two scenarios that are optimistic and pessimistic with this model.
\end{abstract}

Keywords: COVID-19, SIR, coronavirus, prediction.

2010 Mathematics Subject Classification: 00A69 


\section{PENDAHULUAN}

Munculnya wabah COVID-19 yang melanda dunia telah menjadi perhatian berbagai pihak karena cepatnya tingkat penyebaran wabah dan banyaknya kasus kematian yang terjadi. Beberapa kajian mulai dilakukan untuk mempelajari karakteristik penyakit ini, seperti cara penyebaran, kemampuan bertahan di beberapa media dan zat-zat kimia yang dapat digunakan untuk melumpuhkan virus tersebut, lihat [2].

Kajian tentang prediksi endemi COVID-19 di China sebagai pusat penyebaran virus ini untuk pertama kali, telah dilakukan oleh Roosa, dkk, lihat [3]. Metode yang digunakan dalam kajian tersebut adalah metode GLM dan model Richards untuk prediksi kasus secara kumulatif di China. Prediksi terhadap pandemi selalu berdasarkan faktor-faktor sebagai berikut: karakteristik dari penyebab pandemi, karakteristik komunitas atau individu yang terkena, karakteristik geografi, dan kebijakan serta kemampuan sistem kesehatan. Namun tidak semua faktor dapat dikaji secara bersamaan oleh karena masih lemahnya pemahaman dan ketersediaan data [6]. Modelling sangat diperlukan untuk mengendalikan penyakit infeksi, terutama untuk mengembangkan strategi mitigasi 7 .

Pemodelan matematika tentang epidemi berbasis SIR dan SI sudah diperkenalkan oleh Kermack-McKendrick, lihat [1]. Di [1] juga di bahas metode untuk melakukan estimasi parameter dari model SIR dan SI yang berupa sistem persamaan diferensial dengan menggunakan metode Ordinary Least Square dan metode Nelder-Mead Simplex. Pada penelitian ini, akan disampaikan dua jenis prediksi kasus COVID-19 di Provinsi DIY berbasis model SIR berdasarkan data dari Gugus Tugas COVID-19 DIY (corona.jogjaprov.go.id) tanggal 1 April 2020 sampai dengan 24 April 2020. Skenario optimistik dari data diprediksi menggunakan model SIR dengan menggabungkan metode Ordinary Least Square, NelderMead Simpleks, dan Runge-Kutta orde 4. Sementara itu skenario pesimistik dari data diprediksi menggunakan model yang sama dengan menggabungkan kurva fitting dan least square estimation terhadap data training. Pada skenario kedua ini, prediksi banyak kasus terkonfirmasi untuk beberapa hari ke depan juga diberikan dengan terlebih dahulu memprediksi banyak pasien dalam pengawasan (PDP).

\section{MODEL PENYEBARAN COVID-19 BERBASIS SIR}

Model SIR merupakan model epidemi yang dilakukan dengan mengelompokkan populasi ke dalam tiga kelas yang saling asing, yaitu kelas individu rentan yang dapat terinfeksi (Susceptible - S), kelas individu terinfeksi (Infected - I), dan kelas individu yang sembuh dari sakit (Recovered - $R$ ). Selanjutnya, ketika individuindividu di ketiga kelas tersebut saling berinteraksi, maka banyaknya individu 
pada kelas terinfeksi dan kedua kelas lainnya pada waktu tertentu dapat diketahui.

Model SIR yang digunakan dalam melakukan prediksi kasus COVID-19 untuk wilayah DIY ini adalah sebagai berikut.

$$
\left\{\begin{array}{l}
\frac{d S}{d t}=-\frac{\beta S I}{N} \\
\frac{d I}{d t}=\frac{\beta S I}{N}-\gamma I \\
\frac{d R}{d t}=\gamma I
\end{array}\right.
$$

dengan $\beta$ adalah parameter menyatakan tingkat infeksi, yaitu banyaknya interaksi antara individu rentan dengan individu yang telah terinfeksi yang menyebabkan seorang individu menjadi terinfeksi. Sementara itu, $\gamma$ adalah parameter yang menyatakan tingkat kesembuhan seorang pasien yang terinfeksi. Kedua nilai parameter tersebut, diestimasi dari data dengan menggunakan metode Ordinary Least Square (OLS) yang digabungkan dengan metode Nelder-Mead Simplex, dan metode Runge-Kutta berorde 4. Pada ruas kiri, $d S / d t, d I / d t$, dan $d R / d t$ menyatakan laju perubahan banyaknya individu pada kelas $S$, kelas $I$, dan kelas $R$. Parameter $N=S+I+R$ merupakan total populasi yang memiliki perilaku hampir sama (homogen).

Dari Model 2.1), diperoleh bilangan reproduksi dasar $R_{0}=\beta / \gamma$ [5]. Nilai ini menunjukkan index terjadinya penularan wabah. Apabila nilai $R_{0}>1$, maka banyaknya infeksi baru akan lebih besar dibanding banyaknya individu yang sembuh.

\section{PENERAPAN PADA KASUS COVID-19 DI DIY}

Dalam kasus ini diasumsikan bahwa nilai $N=10.000$. Hal ini didasarkan pada fakta bahwa banyaknya ODP (Orang Dalam Pemantauan), PDP (Pasien Dalam Pemantauan), dan pasien positif di wilayah DIY berdasarkan data masih di bawah 4.100 dan jumlah dari ketiga komponen tersebut masih jauh di bawah 10.000 orang. Asumsi ini digunakan karena di dalam model SIR perilaku individu di masing-masing kompartemen punya pola yang seragam. Seragam atau homogen yang dimaksud adalah masyarakat memiliki tingkat kedisiplinan dan respon yang sama atau hampir sama terhadap wabah ini. Perilaku tersebut yang dipotret dengan model SIR ini.

\subsection{Pertumbuhan Alami COVID-19 berdasarkan model SIR}

Regulasi pemerintah saat ini mengatur bahwa pasien dalam pengawasan (PDP) yang meninggal diperlakukan seperti halnya pasien positif COVID-19. Berdasarkan fakta tersebut, di dalam model ini PDP dianggap sebagai pasien yang terinfeksi COVID-19. Berdasarkan hasil tes yang dilakukan di masyarakat, ditemukan fakta 
bahwa terdapat orang yang tampak sehat namun ternyata terinfeksi COVID-19. Masyarakat dengan kondisi seperti ini dikelompokkan ke dalam orang tanpa gejala (OTG). Berbeda dengan orang dalam pengawasan (ODP) dan PDP yang dikarantina atau melakukan karantina mandiri selama minimal 14 hari, masyarakat yang berada dalam kelompok OTG ini berinteraksi secara normal di masyarakat. Dengan demikian, keberadaan OTG ini perkirakan menjadi salah satu faktor kunci dalam penyebaran COVID-19.

Di dalam skenario ini, individu yang masuk dalam kategori PDP yang masih dalam proses menunggu hasil tes dan PDP yang meninggal diasumsikan masuk dalam kasus positif terinfeksi COVID-19. Dengan demikian, banyaknya individu terinfeksi merupakan jumlahan dari banyaknya PDP yang masih dalam proses menunggu hasil tes, banyaknya PDP yang meninggal, banyaknya pasien positif yang dirawat, banyaknya pasien positif yang meninggal, dan banyaknya Orang Tanpa Gejala (OTG) yang ada di masyarakat. Berhubung data banyaknya OTG sulit didapatkan, maka pada model ini diasumsikan bahwa banyaknya OTG di masyarakat adalah sama dengan banyaknya ODP. Data individu terinfeksi dapat dilihat pada TABEL 1 .

TABEL 1. Banyaknya individu terinfeksi. Data tanggal 06/04/2020 merupakan data hasil estimasi. Sumber data: Gugus Tugas COVID-19 DIY (https://corona.jogjaprov.go.id).

\begin{tabular}{|l|r|r|r|r|r|}
\hline Tanggal & $\begin{array}{c}\text { Individu } \\
\text { Terinfeksi }\end{array}$ & Tanggal & $\begin{array}{c}\text { Individu } \\
\text { Terinfeksi }\end{array}$ & Tanggal & $\begin{array}{l}\text { Individu } \\
\text { Terinfeksi }\end{array}$ \\
\hline \hline $01 / 04 / 20$ & 2777 & $09 / 04 / 20$ & 3327 & $17 / 04 / 20$ & 3979 \\
\hline $02 / 04 / 20$ & 2423 & $10 / 04 / 20$ & 3505 & $18 / 04 / 20$ & 3960 \\
\hline $03 / 04 / 20$ & 2588 & $11 / 04 / 20$ & 3562 & $19 / 04 / 20$ & 3966 \\
\hline $04 / 04 / 20$ & 2587 & $12 / 04 / 20$ & 3582 & $20 / 04 / 20$ & 3964 \\
\hline $05 / 04 / 20$ & 2587 & $13 / 04 / 20$ & 3657 & $21 / 04 / 20$ & 3983 \\
\hline $06 / 04 / 20^{*}$ & 2900 & $14 / 04 / 20$ & 3680 & $22 / 04 / 20$ & 3991 \\
\hline $07 / 04 / 20$ & 3131 & $15 / 04 / 20$ & 3755 & $23 / 04 / 20$ & 4176 \\
\hline $08 / 04 / 20$ & 3169 & $16 / 04 / 20$ & 3966 & $24 / 04 / 20$ & 4264 \\
\hline
\end{tabular}

Dari estimasi parameter yang dilakukan diperoleh nilai tingkat infeksi untuk wilayah DIY adalah sebesar 12,25\% dengan tingkat kesembuhan pasien sebesar $3,77 \%$. Dengan menggunakan hasil ini, diperoleh bilangan reproduksi dasar $R_{0}$ sebesar 3, 25. Nilai ini berarti bahwa satu orang terinfeksi berpotensi menularkan virus COVID-19 kepada 3 sampai 4 orang yang sehat.

Prediksi pola infeksi berdasarkan model SIR dan data dapat dilihat pada GAMBAR 1 . 


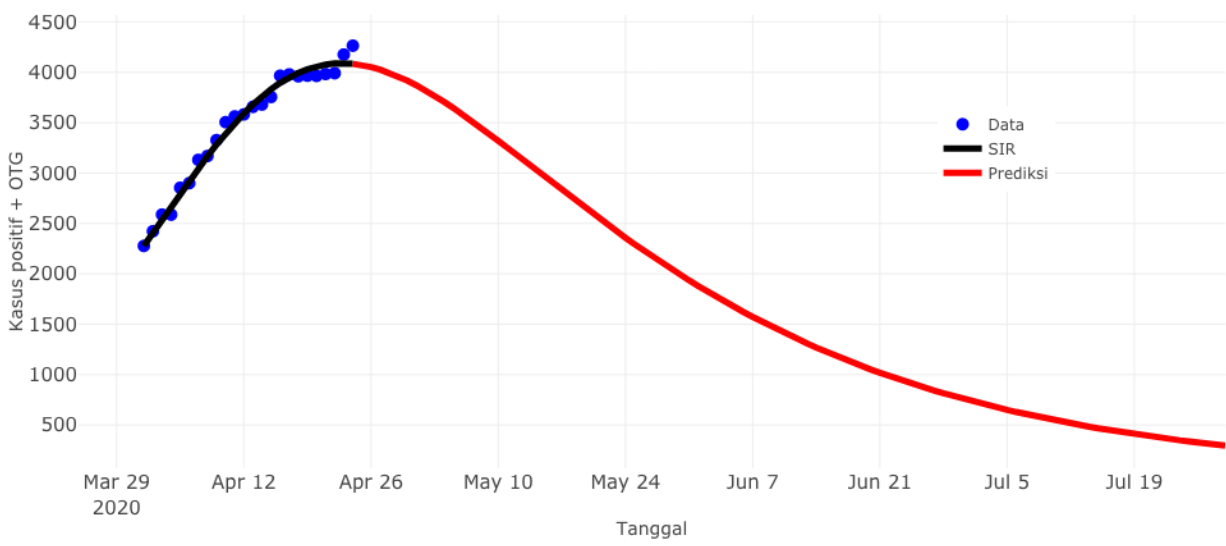

Gambar 1. Prediksi pola infeksi

Dapat dilihat bahwa pediksi banyaknya individu terinfeksi (Positif dan OTG) hingga 120 hari (mulai 1 April 2020). Penyelesaian dari Model SIR, yaitu Model 2.1) ditunjukkan oleh kurva berwarna hitam. Kurva berwarna biru diperoleh berdasarkan data pada TABEL 1, dan kurva berwarna merah merupakan prediksi berdasarkan Model (2.1). Hasil tersebut juga menunjukkan bahwa banyaknya Kasus Positif dan OTG akan mengalami penurunan secara signifikan dan akan menuju nol setelah 120 hari (4 bulan). Dengan demikian, kasus aktif diperkirakan akan mulai berkurang secara signifikan pada bulan Agustus 2020. Jika banyaknya OTG lebih sedikit dari asumsi di atas, maka pengurangan kasus secara signifikan juga terjadi lebih cepat.

\subsection{PDP berpotensi sudah terinfeksi}

Berbeda dengan sub-bab sebelumnya yang hanya memproyeksikan durasi atau lama wabah di DIY, pada sub-bab ini akan dilakukan juga prediksi banyak kasus terkonfirmasi dengan cara terlebih dahulu memprediksi banyak PDP. Dengan menggunakan regresi linier sederhana [4. Dengan fakta bahwa PDP merupakan orang dengan infeksi saluran pernapasan akut (ISPA) yaitu demam (dengan suhu lebih dari 38 derajat Celcius) dan disertai dengan batuk/sesak napas/sakit tenggorokan/pilek/pneumonia ringan hingga berat, dan orang tersebut memiliki riwayat perjalanan atau tinggal di negara/wilayah yang melaporkan transmisi lokal pada 14 hari terakhir sebelum gejala timbul, di dalam skenario ini PDP yang belum sembuh atau meninggal dimasukkan sebagai kelas infected $(I)$. Sedangkan kelas recovered $(R)$ didefinisikan sebagai orang yang sudah meninggalkan kelas $I$ baik karena sembuh atau karena meninggal. Jika semua orang di kelas $I$ dikarantina atau mengisolasi secara mandiri maka tidak akan ada rekrutmen ke kelas $I$. Hanya saja, pada kenyataannya masih ada kasus PDP baru. Artinya bahwa ada orang 
terinfeksi di luar yang dilaporkan dan dapat menularkan wabah. Pada skenario ini, diasumkan bahwa banyak orang terinfeksi yang tidak terdeteksi tersebut sama dengan banyak PDP.

Kumulatif dari banyak PDP dinotasikan dengan $K$ (kumulatif) dan berdasar Model (2.1) memenuhi persamaan diferensial

$$
\frac{d K}{d t}=\frac{\beta S I}{N} .
$$

Dengan anjuran dari Kementrian Kesehatan agar PDP (yang tidak perlu perawatan medis) diminta untuk melakukan isolasi mandiri selama 14 hari, maka tingkat kesembuhan $\gamma$ diasumsikan 1/14. Tingkat infeksi $\beta$ diestimasi berdasar data PDP Provinsi DIY dengan menggunakan metode OLS. Data ODP, PDP, dan kasus terkonfirmasi Covid-19 di DIY tersedia dari tanggal 1 - 24 April 2020. Hanya saja, tanggal 6 April tidak ada data. Berbeda dengan sub-bab sebelumnya yang mengestimasi data tanggal 6 April, di sini data yang digunakan untuk estimasi dimulai dari data tanggal 7 April. Untuk melihat gambaran penuh masa kesembuhan 14 hari, diambil sebanyak 14 hari data untuk estimasi parameter $\beta$. Ini berarti bahwa data yang digunakan untuk estimasi (selanjutnya disebut data training) adalah data tanggal 7 - 20 April 2020 sedangkan data tanggal 21-24 digunakan untuk melihat performa model prediksi. Dari data training tersebut diperoleh syarat awal $S(0)=9.669, I(0)=209$, dan $K(0)=331$. Data PDP ini disajikan pada TABEL2.

TABEL 2. Banyaknya kumulasi PDP (merah: tidak digunakan, hitam: training, biru: testing)

\begin{tabular}{|l|r|r|r|r|r|}
\hline Tanggal & PDP & Tanggal & PDP & Tanggal & PDP \\
\hline \hline $01 / 04 / 20$ & 181 & $09 / 04 / 20$ & 346 & $17 / 04 / 20$ & 537 \\
\hline $02 / 04 / 20$ & 196 & $10 / 04 / 20$ & 402 & $18 / 04 / 20$ & 552 \\
\hline $03 / 04 / 20$ & 255 & $11 / 04 / 20$ & 404 & $19 / 04 / 20$ & 569 \\
\hline $04 / 04 / 20$ & 269 & $12 / 04 / 20$ & 426 & $20 / 04 / 20$ & 581 \\
\hline $05 / 04 / 20$ & 295 & $13 / 04 / 20$ & 450 & $21 / 04 / 20$ & 599 \\
\hline $06 / 04 / 20$ & - & $14 / 04 / 20$ & 472 & $22 / 04 / 20$ & 616 \\
\hline $07 / 04 / 20$ & 331 & $15 / 04 / 20$ & 486 & $23 / 04 / 20$ & 638 \\
\hline $08 / 04 / 20$ & 343 & $16 / 04 / 20$ & 518 & $24 / 04 / 20$ & 649 \\
\hline
\end{tabular}

Metode OLS diaplikasikan pada data kumulatif kasus PDP. Estimasi $\hat{\beta}$ dipilih sedemikian rupa sehingga

$$
\frac{1}{14} \sum_{t=1}^{14}(\hat{K}(t)-K(t))^{2}
$$


minimal dengan $(\hat{K}(t)$ merupakan hasil prediksi kumulatif kasus PDP dengan $\beta=\hat{\beta}$ dan $\gamma=1 / 14$. Hasil dari estimasi beta adalah $\hat{\beta}=9,12 \%$ dengan kecocokan model seperti terlihat pada Gambar 2 .

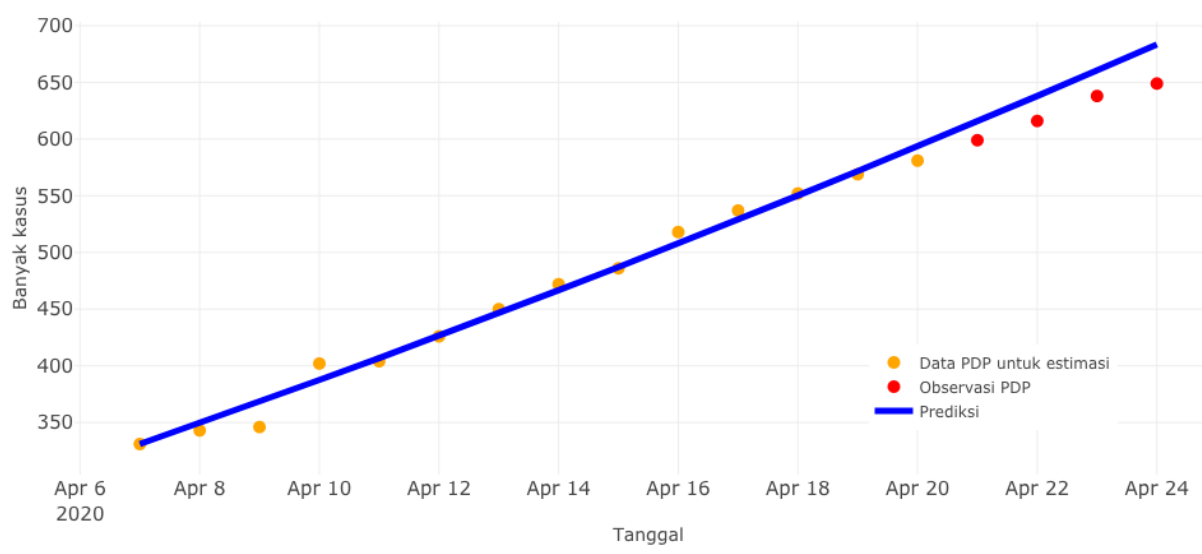

Gambar 2. Kecocokan model

Dengan hasil estimasi ini, dengan asumsi bahwa interaksi populasi masih seperti sekarang dan tidak ada kebijakan pemerintah lebih lanjut, wabah Covid-19 ini baru akan berakhir setelah Maret 2021 dengan puncak kasus terjadi pada sekitar pertengahan Juni dengan banyak kasus aktif sekitar 400 orang seperti tampak pada Gambar 3.

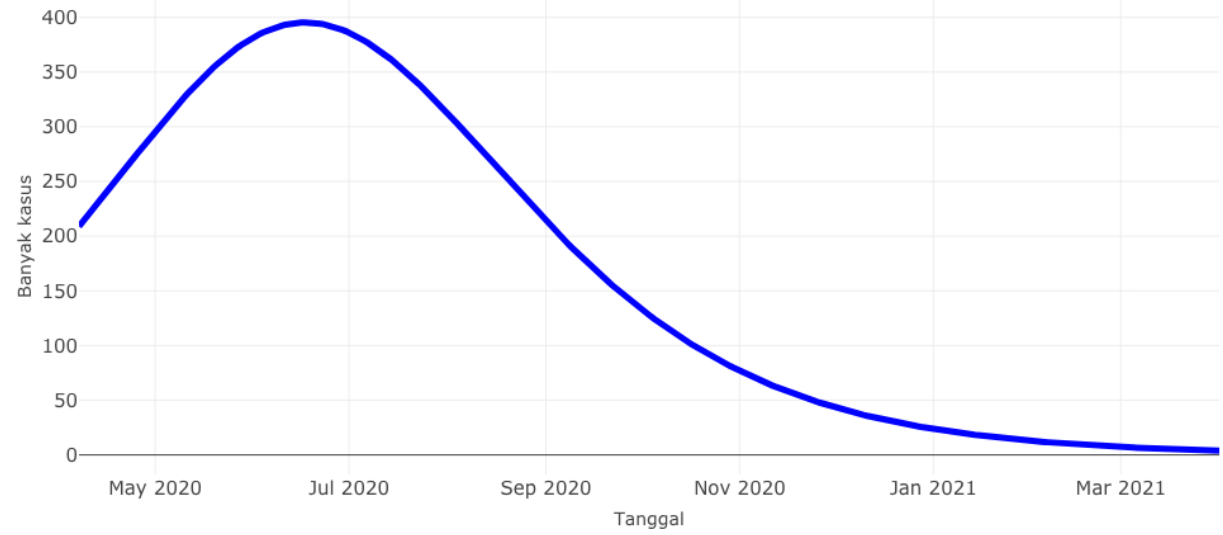

Gambar 3. Proyeksi kasus aktif 
Prediksi jangka pendek banyak kasus terkonfirmasi juga dapat dilakukan dengan menggunakan regresi linier $P(t)=r K(t)$ dengan $r$ diestimasi menggunakan OLS. Hasil estimasi untuk $r$ adalah $\hat{r}=11.3 \%$ dengan $95 \%$ interval konfidensi $[10.9 \%, 11.7 \%]$. Ini artinya bahwa kasus positif sekitar $11.3 \%$ dari banyak PDP. Hasil prediksi dari model ini diberikan pada TABEL 3

TABEL 3. Prediksi banyak kasus terkonfirmasi

\begin{tabular}{|l|r|l|}
\hline Tanggal & \multicolumn{1}{|c|}{ Data } & Prediksi \\
\hline 21 April & 69 & $67-73$ \\
\hline 22 April & 72 & $69-75$ \\
\hline 23 April & 75 & $72-78$ \\
\hline 24 April & 76 & $74-81$ \\
\hline 25 April & belum ada & $77-83$ \\
\hline 26 April & belum ada & $79-86$ \\
\hline 27 April & belum ada & $82-89$ \\
\hline 28 April & belum ada & $84-92$ \\
\hline 29 April & belum ada & $87-94$ \\
\hline 30 April & belum ada & $90-97$ \\
\hline
\end{tabular}

\section{KESIMPULAN DAN REKOMENDASI}

Dari hasil kajian yang dilakukan dapat disimpulkan bahwa dengan asumsi banyaknya OTG sama dengan banyaknya ODP di masyarakat, maka penyebaran COVID-19 diperkirakan baru akan menurun secara signifikan pada bulan Agustus 2020. Ini adalah perkiraan paling optimis yang dapat diprediksi berdasarkan data dan model SIR.

Dengan menggunakan pendekatan berbeda yaitu dengan menganggap bahwa PDP sangat berpotensi sudah terinfeksi, maka dengan situasi seperti saat ini, diperkirakan wabah baru akan menurun secara signifikan pada bulan Maret 2021 mendatang. Puncak kasus terjadi sekitar pertengahan Juni dengan banyak kasus aktif terdeteksi sekitar 400 orang. Kasus aktif ini merupakan banyak PDP yang belum sembuh atau belum meninggal dan sudah diminta untuk karantina atau sudah diisolasi. Artinya, dengan melihat fakta bahwa masih adanya arus rekrutmen ke kelas PDP mengindikasikan bahwa masih ada orang terinfeksi di luar yang tidak dikarantina atau tidak mengisolasi diri. Mereka bisa saja orang tanpa gejala (OTG) atau penularan sebelum gejala sakit muncul (pre-symptomatic transmission.)

Hal yang perlu diperhatikan bahwa simulasi pada artikel ini berdasar pada data setelah DIY melakukan penutupan tempat-tempat umum seperti sekolah, pasar, dan yang lainnya. Artinya, jika fasilitias-fasilitas umum tersebut dibuka kembali, kemungkinan tingkat infeksi akan membesar dan mengakibatkan kasus 
positif juga lebih banyak. Untuk mempercepat penurunan wabah COVID-19 di DIY, ada beberapa rekomendasi yang dapar disampaikan. Pertama, penegakan aturan pembatasan sosial dan kemungkinan untuk melakukan karantina wilayah. Hal ini akan menurunkan tingkat infeksi atau tingkat penularan COVID-19. Kedua, perlu pendataan tentang kapasitas dan fasilitas rumah sakit di wilayah DIY yang dapat digunakan untuk merawat pasien COVID-19. Hal ini penting untuk meningkatkan tingkat kesembuhan pasien positif. Ketiga, pendataan OTG berdasarkan contact tracing masyarakat dengan PDP dan pasien positif, dan pemantauan secara melekat terhadap ODP, dengan menggunakan kombinasi antara media digital dengan pengawasan sosial.

Di dalam artikel ini, kapasitas untuk melakukan rapid tes, akurasi dari hasil rapid tes, dan kemampuan untuk melakukan tes diganostik, sangat mempengaruhi angka-angka kejadian yang dicatat. Oleh sebab itu, data yang akurat akan membuat prediksi menjadi semakin baik sehingga model semakin merepresentasikan kejadian yang sesungguhnya. Model sederhana dalam artikel ini, dapat dikembangkan untuk mendapatkan hasil yang lebih akurat dengan mengkaji lebih rinci pembagian populasinya seperti model berbasis SEIRHD (Susceptible: orang yang tidak terinfeksi tetapi dapat terinfeksi, Exposed: orang yang terinfeksi namun tanpa gejala, Infectious: orang yang terinfeksi dan terdeteksi, Hospitalized: orang yang sudah terinfeksi dan dirawat di rumah sakit, Recovered: orang yang terinfeksi dan sembuh, dan Death: orang yang terinfeksi dan meninggal.

Ucapan Terima Kasih. Penulis mengucapkan terima kasih kepada Gugus Tugas COVID-19 DIY (https://corona.jogjaprov.go.id) atas dukungan data harian untuk kasus COVID-19 DIY yang digunakan dalam penelitian ini. Penulis juga mengucapkan terima kasih yang sebesar-besarnya Tim Departemen Matematika FMIPA UGM untuk Pemodelan COVID-19 DIY dan kepada Universitas Gadjah Mada atas segala fasilitas yang diberikan.

\section{REFERENSI}

[1] F. Brauer and C. Castillo-Chavez, Mathematical Models in Population Biology and Epidemiology, 2nd Ed., New York Dordrecht Heidelberg London : Springer, 2012.

[2] S. Kampf, D. Todt, S. Pfaender and E. Steinmann, Persistence of coronaviruses on inanimate surfaces and their inactivation with biocidal agents, Journal of Hospital Infection 104 (2020), 246-251.

[3] K. Roosa, Y. Lee, R. Luo, A. Kirpich, R. Rothenberg, J. M. Hyman, P. Yan and G. Chowell, Short-term Forecasts of the COVID-19 Epidemic in Guangdong and Zhejiang, China: February 13?23, 2020, Journal of Clinical Medicine 5(596) (2020).

[4] Kenney, J. F. and Keeping, E. S., Mathematics of Statistics, Ch. 15, 3rd ed. Princeton, NJ: Van Nostrand, 1962. 
[5] O. Diekmann, J. A. P. Heesterbeek, J. A. Metz, On the definition and the computation of the basic reproduction ratio R0 in models for infectious diseases in heterogeneous populations, J. Math. Biol. 28 (1990), 265-382.

[6] Qianying Lin, Shi Zhao, Daozhou Gao, Yijun Lou, Shu Yang, Salihu S. Musa, Maggie H. Wang, Yongli Cai, Weiming Wang, Lin Yangh, Daihai He, A conceptual model for the coronavirus disease 2019 (COVID-19) outbreak in Wuhan, China with individual reaction and governmental action, International Journal of Infectious Diseases 93 (2020), 211-216.

[7] Faical Ndairou and Ivan Area and Juan J. Nieto and Delfim F.M. Torres, Mathematical Modeling of COVID-19 Transmission Dynamics with a Case Study of Wuhan, Chaos, Solitons 8 Fractals 109 (2020), 109846.

\section{FAJAR Adi-Kusumo}

Departemen Matematika, Fakultas Matematika dan Ilmu Pengetahuan Alam, Universitas Gadjah Mada, Sekip Utara Yogyakarta 55281, INDONESIA.

f_adikusumo@ugm.ac.id

NAnAng Susyanto* (Penulis korespondensi)

Departemen Matematika, Fakultas Matematika dan Ilmu Pengetahuan Alam, Universitas Gadjah Mada, Sekip Utara Yogyakarta 55281, INDONESIA.

nanang_susyanto@ugm.ac.id

\section{IRWAN ENDRAYANTO}

Departemen Matematika, Fakultas Matematika dan Ilmu Pengetahuan Alam, Universitas Gadjah Mada, Sekip Utara Yogyakarta 55281, INDONESIA.

endrayanto@ugm.ac.id

\section{Andreasta Meliala}

Pusat Kebijakan dan Manajemen Kesehatan, Fakultas Kedokteran, Kesehatan Masyarakat, dan Keperawatan, Universitas Gadjah Mada, Sekip Utara Yogyakarta 55281, INDONESIA.

andremeliala@ugm.ac.id 